Klaus Oschema

\title{
Heaven Can Tell ... Late Medieval Astrologers as Experts - and what they can Teach us about Contemporary Financial Expertise
}

\begin{abstract}
In taking action, or rather in making the decision to act, humans are inevitably confronted with a fundamental dilemma: actions taken in the present seek to bring about consequences in an immediate or distant future, but that future is, by definition, unknown and unknowable. That even the present is characterized by a high degree of complexity can lead to the establishment of a particular group: experts or expert advisers. Experts are individuals credited with specific knowledge and who are relied upon in order to make informed decisions or solve particular problems. While many authors consider the development of cultures of expertise to be a uniquely modern phenomenon that responds to the increasing complexity of social organisation, this chapter argues that late medieval astrologers can be described as 'experts', and that their activities can be analysed fruitfully as being part of an 'expert culture'. In order to appreciate fully the characteristics and workings of this culture, medievalists have to rely upon insights and findings derived from the Social Sciences. While an interdisciplinary dialogue benefits research on medieval subjects, I argue that the analysis of premodern 'expert culture' can (and must) inform reflexions on the role of experts in modern societies. Based on drawing a comparison between modern financial experts and late medieval astrologers, I argue that analysis of the latter enables us to better understand our reliance on experts as an act of belief rather than as an outcome of supposedly rational calculation.
\end{abstract}

Keywords: expert culture, science, astrology, economics, forecast, prognostication, failure

\section{Prelude}

In order to demonstrate the potential and relevance of Medieval Studies for contemporary society, it seems helpful to start in the present. Many people would certainly agree that the years after 1989/90 have seen the development of an increasingly complex world on several levels. The previous, more or less clear-cut political order that saw a capitalist 'West' confront the communist 'East' has been rapidly transformed

\footnotetext{
Klaus Oschema, Geschichte des Mittelalters (insb. des späten Mittelalters), Ruhr-Universität Bochum, Historisches Institut, Universitätsstr. 150, 44801 Bochum, Germany, klaus.oschema@rub.de 
into a profoundly complex multitude of political entities with varying and sometimes unclear political orientations and affiliations. Intensified economic exchange on a global scale has benefitted large numbers of consumers, but has equally created problematic side-effects such as the economic 'migrations' of large corporations that seek to minimize their tax obligations while siting manufacturing facilities in locations where they can fabricate their products at cheaper rates (and where regulations are often less strict). International travel has vastly expanded, making people more mobile, but also distributing pathogens more efficiently (such as the 'pig-flu' and the 'bird-flu') and fostering tensions than can be interpreted, depending on one's perspective, in religious or social terms. In the aftermath of the events of 9/11/2001 that played a decisive role for many ensuing political and cultural developments, both of these dimensions converged. To cut a long story short: the world 'we' live in has become awfully complex and complicated (especially since this 'we' obviously refers to radically divergent realities, depending on the individual chance of being born into a well-off family in Switzerland or a poor family elsewhere!).

In order to 'navigate' this increasingly complicated world, contemporary societies and their members rely on a specific group: experts! Experts are the people who are recognized to have deeper insights than the average person in their particular area of expertise, and thus are supposed to be able to help us to better understand specific contexts or problems and to master successfully specific tasks. ${ }^{1}$ This approach is by no means neutral and exclusively concerned with providing us with a better sense of the world we inhabit. It rather fulfils essential and very practical functions, allowing us to take informed decisions in the present - and in order to do so, experts frequently offer prognostications about the future. ${ }^{2}$

1 Among the vast body of pertinent recent publications I would mention only Stephen P. TURNER, The Politics of Expertise (Routledge Studies in Social and Political Thought 82), New York, London 2013, who analyses the political implications of experts' prominent role; the contributions in Karl Anders Ericsson / Neil Charness / Paul J. Feltovich / Robert R. Hoffmann (eds.), The Cambridge Handbook of Expertise and Expert Performance, Cambridge, New York 2006, mostly focus on questions concerning the improvement and practical application of expertise. For a critical analysis see already Anthony GIDDENS, The Consequences of Modernity, Cambridge 1990.

2 See e. g. Dan Gardner, Future Babble. Why Expert Predictions Fail - and Why We Believe Them Anyway, Toronto 2010; Philip E. TetLock, Expert Political Judgment: How Good Is It? How Can We Know?, Princeton / NJ 2005; ID. / Dan GARDNER, Superforecasting. The Art and Science of Prediction, London 2016 (orig. New York 2015). For a specific model see Denis LovERIDGE, Foresight. The Art and Science of Anticipating the Future, New York 2009. A short critical analysis is provided by Fernand GoBET, Understanding Expertise. A Multi-Disciplinary Approach, London 2016, pp. 185-192. In the present study, I reserve the notion "forecast" / "forecasting" for modern procedures of financial and economic descriptions of probable future developments. As my argument will hopefully make clear, however, the differences between "modern forecasts" and "premodern prognostications" are not clear enough to warrant a precise distinction (which is, in fact, also reflected in the variable use of "forecast", "prediction", and "prognostication" in the cited literature). 
But the increasing importance of experts also entails a profound unease with the complexity of the modern world and the necessity of relying on expert counsel in a broad range of situations, from tax declarations and pension schemes to political decisions. This unease originates from a feeling of helplessness when confronted with the unclear consequences of individual actions, but also with the experience of experts' failures that can be witnessed in the media. 'Western' societies are thus facing a paradoxical situation: relying more and more on experts on the one hand, on the other hand they develop an 'anti-expert'-stance that underlines the importance of lay-people and 'common sense'. The experts' position is thus frequently criticized as being unmerited, since it allegedly results from purely formal criteria, like the possession of a diploma. ${ }^{3}$ This attitude resonates with the anti-intellectual stance adopted in political discourse in countries like France, Switzerland, or Hungary, and probably also contributed to the election of Donald J. Trump as president of the USA in November 2016.

Leaving genuine politics aside, ${ }^{4}$ a specific group of experts furnishes a telling example of symbolic actions that invite us to reconsider our depiction of 'modern' society as being based on principles such as rationality: since the financial crisis that erupted in 2007, several studies have demonstrated that financial and economic expertise effectively has very limited value when it comes to the prognostication of future developments, ${ }^{5}$ even though this is the main interest of the experts' clients and readers. ${ }^{6}$ We seek advice in order to decide in which form we should invest the money we put aside for use in the (often distant) future, for example for pension plans. But if the success-rate of forecasts drops far enough, tossing a coin would be equally efficient. ${ }^{7}$

3 For this criticism see e. g. Marc E. FITCH, Shmexperts. How Ideology and Power Politics are Disguised as Science, Washington / DC 2015. Adding to the paradox, the popularized presentation of scientific insights leads laypeople to underestimate the complexity of research and its findings, see Lisa SCHARRER / Yvonne RUPIEPER / Marc STADTLER / Rainer BROMME, When Science Becomes Too Easy. Science Popularization Inclines Laypeople to Underrate their Dependence on Experts, in: Public Understanding of Science (2016), online (DOI): http://journals.sagepub.com/doi/10.1177/ 0963662516680311 (last accessed 15/05/2019).

4 The need to rely on experts can in fact entail serious (theoretical and practical) difficulties for democratic processes and structures, see TURNER (note 1), pp. 3-5.

5 See note 2 and several studies by Markus SpIwoKs, e. g. ID. / Johannes ScheIER / Oliver HEIn, On Assessing Economic Forecasts. An Evaluation of Predictions on GDP, Industrial Production and Private Consumer Spending Trends in Twelve Industrial Nations, in: Advances in Management and Applied Economics 4(2) (2014), pp. 49-68.

6 See, however, Jens BECKER, Imagined Futures. Fictional Expectations and Capitalist Dynamics, Cambridge / MA 2016, who underlines the systemic value of predictions, which contribute to creating a set of expectations and a general orientation towards expected (i. e. future) growth, that characterizes capitalist mentality as a whole.

7 For the low success of financial forecasts see e. g. Markus SPIwoKs, The Golden Mean Fallacy and Financial Market Forecasting, in: European Journal of Social Sciences 6(3) (2008), pp. 433-441, or ID. / 
This is not the place to present a long list of either anecdotal or more systematic evidence for the long series of failing financial and economic forecasts, although this would provide some very amusing material. ${ }^{8}$ Suffice to say that the leading experts did not see the crisis of 2007 coming - and once it had arrived, they failed to recognize its dimensions, let alone provide satisfying explanations and justifications for their failure. ${ }^{9}$ Moreover, in spite of the apparent disappointment in this particular case, few individual experts - not to mention their entire profession suffered sustained and far-reaching consequences.

There are, of course, good reasons for this, since the failure of forecasts is not equivalent to the uselessness of the experts' assessment of the present. But the particular combination of failure and continuing practice as someone who is recognized as being an authority in predicting the future invites the medievalist to have a closer and comparative look at a phenomenon that belongs to her or his own area of expertise: the rise of astrologers as experts and scientific advisers to rulers in the fourteenth and fifteenth centuries. Even though I would not want to put modern financial and economic experts on a par with these astrologers, ${ }^{10}$ I would like to argue that their practices, as well as their social roles, resemble each other to such a degree that it warrants a comparative analysis, which in turn can shed new light on both subjects. If this really is the case, however, it implies a high degree of

Oliver HEIN, Die Währungs-, Anleihen- und Aktienmarktprognosen des Zentrums für Europäische Wirtschaftsforschung. Eine empirische Untersuchung des Prognoseerfolges von 1995 bis 2004, in: AStA - Wirtschafts- und Sozialstatistisches Archiv 1(1) (2007), pp. 43-52. See also BECKER (note 6), pp. 217-244.

8 See e. g. GARDNER (note 2).

9 Ibid., pp. 13-14; BECKER (note 6), p. 222. I would like to thank H. Darrel RUTKIN for pointing out the analogy with the situation in 1524-1525: while a large number of astrologers predicted a great flood that failed to materialize, none of them seems to have foreseen the Peasants' War of 1525, see Ottavia Niccolì, Prophecy and People in Renaissance Italy, Princeton 1990, and Heike TALKEnBERger, Sintflut. Prophetie und Zeitgeschehen in Texten und Holzschnitten astrologischer Flugschriften 1488-1528 (Studien und Texte zur Sozialgeschichte der Literatur 26), Tübingen 1990. It is interesting to note that Johannes Carion, who enjoyed the reputation of being an extremely successful astrologer, did not predict a flood for 1524, see Frank Ulrich PRIETZ, Das Mittelalter im Dienst der Reformation: Die 'Chronica' Carions und Melanchthons von 1532. Zur Vermittlung mittelalterlicher Geschichtskonzeptionen in die protestantische Historiographie (Veröffentlichungen der Kommission für geschichtliche Landeskunde in Baden-Württemberg. Reihe B: Forschungen 192), Stuttgart 2014, p. 469. On the continuing importance of astrology in the 16th century see, e. g., Claudia Brosseder, Im Bann der Sterne. Caspar Peucer, Philipp Melanchthon und andere Wittenberger Astrologen, Berlin 2004.

10 Even though the comparison has become increasingly common in recent years, see, for example, for Babylonian diviners and astrologers Stefan M. MAUL, Die Wahrsagekunst im Alten Orient, Munich 2013, p. 319, and for medieval astrologers Monica AzzolinI, The Duke and the Stars. Astrology and Politics in Renaissance Milan, Cambridge / MA, London 2013, pp. 63-64, 125. Cf. also Ann Geneva, Astrology and the Seventeenth Century Mind. William Lilly and the Language of the Stars, Manchester, New York 1995, pp. xv-xvi. 
relevance of medieval studies, since they apparently can help us to better understand the workings of our own societies in a very concrete way.

\section{A Science and its Representatives - Remarks on Late Medieval Astrology}

For the sake of brevity, I will not discuss in detail whether or not late medieval astrologers ${ }^{11}$ can indeed adequately be described and understood as 'experts' and as practitioners of a 'science'. Recent research frequently uses the former notion; ${ }^{12}$ as to the latter, they themselves formulated corresponding claims, thus distinguishing themselves from other varieties of prognosticators. Moreover, even their adversaries frequently categorized astrology as 'science' (scientia/science) rather than an 'art' (ars), ${ }^{13}$ and modern historians of science have long recognized the importance of late medieval and early modern astrology for the development of modern science. ${ }^{14}$

Besides these summary arguments, astrologers' classification as experts and practitioners of a science can equally be justified with structural observations,

11 In contrast to modern usage, medieval authors do not systematically distinguish on the terminological level between the notions of "astronomy" and "astrology", see, for example, Steven VANDEN BROECKE, The Limits of Influence. Pico, Louvain, and the Crisis of Renaissance Astrology (Medieval and Early Modern Science 4), Leiden, Boston 2003, pp. 7-27; for the factual distinction in university curricula, see John NoRTH, Astronomy and Astrology, in: Michael H. SHANK / David C. LINDBERG (eds.), Medieval Science (The Cambridge History of Science 2), Cambridge 2013, pp. 456-484, here pp. 458-459. See also H. Darrel RutKIN, Understanding the History of Astrology (and Magic) Accurately: Methodological Reflections on Terminology and Anachronism, in: Philosophical Readings 7(1) (2015), pp. 42-54, esp. pp. 45-46, who underlines that "[f]rom Ptolemy on, the disciplinary distinction both conceptually and in practice was well understood" (quote p. 46). Since my interest lies in the practice of experts who give advice on the basis of astrological data (in the modern sense), I will consistently call my protagonists "astrologers".

12 See e. g. Darin Hayton, The Crown and the Cosmos. Astrology and the Politics of Maximilian I, Pittsburgh / PA 2015, pp. 64, 68, 116 and passim; Anthony GRAFTon, Cardano's Cosmos. The Worlds and Works of a Renaissance Astrologer, Cambridge / MA, London 1999.

13 On the relationship between the concepts see e. g. the contributions in Ingrid CRAEMERRuegenberg / Andreas SpeER (eds.), Scientia und ars in Hoch- und Spätmittelalter (Miscellanea Mediaevalia 22), Berlin, New York 1994. On the question of terminology see e. g. the justification of a broad definition in Michael H. SHANK / David C. LinDBERG, Introduction, in: SHANK / LINDBERG (note 11), pp. 1-26, here pp. 5-8. The fundamental evolution of the very notion of "science" is demonstrated by Stephan MeIER-Oeser / Helmut HüHn / Helmut Pulte, Wissenschaft, in: Historisches Wörterbuch der Philosophie, vol. 12 (2004), cols 902-948.

14 See Brendan Dooley, Astrology and Science, in: ID. (ed.), A Companion to Astrology in the Renaissance (Brill's Companions to the Christian Tradition 49), Leiden, Boston 2014, pp. 233-266, esp. pp. 233-235. Cf. also NoRTH (note 11), and Edward GRANT, The Foundations of Modern Science in the Middle Ages: Their Religious, Institutional, and Intellectual Contexts, Cambridge 1996. 
which also legitimize the comparison with modern financial experts. If we consider intellectual practices to be 'scientific' that rely (for a specific context) on empirical data and analyse them according to a set of methodological procedures and a specific theoretical framework, medieval astrologers certainly qualify: ${ }^{15}$ their data is furnished by celestial movements, which they either observe directly or reconstruct with the help of astronomical tables and mathematical procedures. This data was then organized in an astrological chart that graphically represented the celestial bodies and their positions. (The use of graphic means of representation and the registration of the empirical data in mathematical terms, i. e. numbers, probably contributed significantly to the recognition of astrology as a 'scientific' practice. ${ }^{16}$ )

While readers will hopefully agree with the argument up to this point, things become more problematic with the decisive following step: based (amongst others) on the idea of an intimate macrocosm-microcosm-relationship, astrologers held (and hold) that celestial bodies affect terrestrial events. ${ }^{17}$ Even if (for the Middle Ages) the precise mechanism of the relationship is rarely discussed in detail beyond the general concepts of theories of the elements and the humours, its assumed effects have been amply noted and categorized by a range of authors who acquired authoritative rank. Astrologers in late medieval Latin Europe were influenced by authorities from the Greco-Roman past as well as by Arab authors, whose

15 SHANK / LINDBERG (note 13), p. 6.

16 The persuasive force of graphical presentation is illustrated (in the form of a guidebook) by Gerald E. JonES, How to Lie with Charts, Lincoln / NE 2000; cf. Thomas F. PATTERSON, Jr. / Jonathan G. LEONARD, E-Graphing: Perfection, Paradox or Persuasion, in: Theo BAstiaEnS / Saul CARLINER (eds.), Proceedings of E-Learn: World Conference on E-Learning in Corporate, Government, Healthcare, and Higher Education, Chesapeake / VA 2007, pp. 2077-2085; Aner TAL / Brian WANSINK, Blinded with Science. Trivial Graphs and Formulas Increase Ad Persuasiveness and Belief in Product Efficacy, in: Public Understanding of Science 25(1) (2016), pp. 117-125. On the medieval use of diagrams see recently Henrike HAUG / Christina LECHTERMAnN / Anna RATHMANn-LuTz (eds.), Diagramme im Gebrauch (Das Mittelalter 22[2]), Berlin, Boston 2017.

17 Cf. briefly Nicolas CAMPION, Astrology, in: Anne L. C. RunEHov / Lluis OvIEDo (eds.), Encyclopedia of Sciences and Religions, Dordrecht, New York 2013, pp. 143-148; for a sociological analysis of contemporary practices in France see Arnaud ESQUERRE, Prédire. L'astrologie au XXI ${ }^{\mathrm{e}}$ siècle en France, Paris 2013. See also Kocku VON STUCKRAD, Geschichte der Astrologie. Von den Anfängen bis zur Gegenwart, Munich 2003, esp. ch. 5 (“Entwicklungslinien der modernen Astrologie”). I am very grateful to H. Darrel RUTKIN for pointing out that the theoretical foundations for astrological expertise are much more complex than a simple analogy between macrocosm and microcosm; however, I feel that for my present argument, which does not seek to develop a synthetical view of astrological theory, the abbreviated presentation might suffice. For more detailed information see, e. g., H. Darrel RUTKIN, Astrology, in: Lorraine DASTON / Katharine PARK (eds.), The Cambridge History of Science, vol. 3: Early Modern Science, Cambridge 2008, pp. 542-563, esp. pp. 546-547, and ID., How to Accurately Account for Astrology's Marginalization in the History of Science and Culture: The Central Importance of an Interpretive Framework, in: Early Science and Medicine 23 (2018), pp. 217-243 (with further bibliographical references). I would like to thank the author for providing me with a copy of this most recent article. 
works were translated in large numbers from the twelfth century onwards. Among the most important, we find authors like Alcabitius, Ptolemy, Albumasar, Messahalla, and Haly Abenragel. ${ }^{18}$

Beyond their scientific methodology and their knowledge of pertinent authorities, astrologers also had to fulfil further requirements in order to be recognized as qualified members of their group: they themselves had to convey their results in a specific form, which included the use of a learned vocabulary and of the wellestablished idiom of scientific discourse, i. e. Latin (at least until the mid-fifteenth century). ${ }^{19}$ If we can apply modern observations on the sociology of expertise and the recognition of scientific status, ${ }^{20}$ we are forced to surmise that outward appearance equally played a role: the astrologers' attire and the signs of their trade, like books or an astrolabe, were certainly not unimportant. ${ }^{21}$ This assumption can at least indirectly be corroborated by the observation that the yearly publication of a

18 For a quantitative approach see David JUSTE, The Impact of Arabic Sources on European Astrology: Some Facts and Numbers, in: Agostino PARAVICINI BAGLIANI (ed.), The Impact of Arabic Sciences in Europe and Asia (Micrologus 24), Florence 2016, pp. 173-194. For a more general presentation see Jean-Patrice BoudET, Entre science et nigromance. Astrologie, divination et magie dans l'occident médiéval, $\mathrm{XII}^{\mathrm{e}}-\mathrm{XV}^{\mathrm{e}}$ siècle, Paris 2006; see also Dag Nikolaus HASSE, Success and Suppression. Arabic Sciences and Philosophy in the Renaissance (I Tatti studies in Italian Renaissance history), Cambridge / MA, London 2016, on the complicated relation between Arabic science and Renaissance thinking.

19 The first prognostications in the vernacular appear in the early 15th century, but they remain exceptional. The oldest example of a judicium in French (for 1415) can be found in Paris, Bibliothèque nationale de France, ms. lat. 7443 , fol. $43^{\mathrm{r}}-48^{\mathrm{v}}$, see Jean-Patrice BouDET, Un jugement astrologique en français sur l'année 1415, in: Jacques PAVIOT / Jacques VERGER (eds.), Guerre, pouvoir et noblesse au Moyen Âge. Mélanges en l'honneur de Philippe Contamine, Paris 2000, pp. 111-120; on the manuscript see Jean-Patrice BoudET, Lire dans le ciel. La bibliothèque de Simon de Phares, astrologue du $\mathrm{XV}^{\mathrm{e}}$ siècle (Les publications de Scriptorium 10), Brussels 1994, pp. 113-151, here p. 114 (judicium in early 15th c. hand) and p. 119 (oldest judicium in French). Philippe ConTAmine, Les prédictions annuelles astrologiques à la fin du Moyen Âge: genre littéraire et témoin de leur temps, in: Histoire sociale, sensibilités collectives et mentalités. Mélanges Robert Mandrou, Paris 1985, pp. 191-204, here pp. 196-197, presents several French judicia, the oldest of which dates from 1438. The growing importance of texts in the vernacular can be seen in the production of printed texts from the 1490s onwards, see (for early modern Germany) Jonathan GREEN, Printing and Prophecy. Prognostication and Media Change 1450-1550, Ann Arbor 2012, pp. 112, 123. For further studies on early modern almanacs and prognostications see Elide CASALI, Le spie del cielo: Oroscopi, lunari e almanacchi nell'Italia moderna, Turin 2003 (Italy), and Bernard S. CAPP, Astrology and the Popular Press: English Almanacs 1500-1800, London 1979 (England).

20 Beyond the numerous contributions which focus on discourse analysis, including questions of authority and power, the pertinent literature remains surprisingly sparse. See, however, Harald A. MIEG, Social and Sociological Factors in the Development of Expertise, in: ERICSSON et al. (note 1), pp. 743-760, here p. 746. For a helpful analysis from the perspective of rhetoric see Johanna E. ARTELIUS, The Rhetoric of Expertise, Lanham / MD 2011.

21 A detailed study of this dimension remains a desideratum; I currently prepare a pertinent research-project at the Ruhr-University Bochum. 
judicium anni, which was part of the obligations of the professors of astrology at the University of Bologna in the fifteenth century, could in fact become the occasion of a public performance. ${ }^{22}$

Unfortunately, this performative dimension of the astrologers' role as experts, whose voice was heard and who were paid for their advice, is notoriously hard to analyse, since most of the sources that contain pertinent information were written by their adversaries. ${ }^{23}$ While we do not have detailed 'manuals' for astrologers that would give advice on how to dress and to behave in order to be taken seriously, ${ }^{24}$ their opponents in the competition for social and discursive recognition sometimes present quite astute observations. Even if authors like Henry of Langenstein, Nicole Oresme, or Laurens Pignon in late fourteenth- and early fifteenth-century France and Burgundy mostly focussed on the logical and theological problems of astrology, they did not ignore opportunities to denigrate their adversaries by accusing them of all sorts of fraudulent practices. ${ }^{25}$ In so doing, they left us with valuable quasipsychological insights while also furnishing important material on astrologers' practices. And this is true, even if the polemical position adopted in such critiques makes the data difficult to evaluate.

22 For more details on this particular genre see below, note 52. The public presentation of these short annual prognostications is mentioned by Alexandre TUR, Hora introitus solis in Arietem. Les prédictions astrologiques annuelles latines dans l'Europe du XV $\mathrm{XV}^{\mathrm{e}}$ siècle (1405-1484), Paris (unpubl. PhD-thesis, Université d'Orléans) 2018, pp. 284-285. I am very grateful to the author for kindly providing me with a copy of his work. The fact that the professor of astrology had to publish such a judicium on a yearly basis is attested by the statutes of the University of Bologna from 1405, see briefly Klaus OschemA, Zukunft gegen Patronage? Spätmittelalterliche astrologische Prognostiken und die Kontaktaufnahme mit Mäzenen, in: Bernd BASTERT / Andreas BIHRER / Tino REUVEKAMPFELBER (eds.), Mäzenaten im Mittelalter aus europäischer Perspektive. Von historischen Akteuren zu literarischen Textkonzepten (Encomia Deutsch 4), Göttingen 2017, pp. 267-291, here p. 271.

23 At least this is the current state of our knowledge. Hopefully, future research on yet unpublished material will unearth additional sources; see also the preceding note.

24 Existing textbooks focus on astrological practice itself, i. e. the interpretation of celestial phenomena. In the context of astrological magic, the 'Picatrix' explains how to dress and to behave when conjuring the aid of individual planets; these prescriptions are a functional part of the ritual itself, however, not a para-scientific performative strategy to convince the public, see Picatrix. The Latin version of Ghāyat Al-Hakim, ed. David PINGREE (Studies of the Warburg Institute 39), London 1986, pp. 140-145 (III ix). More general on the 'performative' dimension of expertise in the premodern period see Frank REXroth / Teresa SchröDER-STAPPER (eds.), Experten, Wissen, Symbole. Performanz und Medialität vormoderner Wissenskulturen (Historische Zeitschrift. Beihefte N.F. 71), Munich 2018.

25 Most recently on late medieval criticism of astrology Carl Philipp Emanuel NothAFт, Vanitas vanitatum et super omnia vanitas: The Astronomer Heinrich Selder and a Newly Discovered Fourteenth-Century Critique of Astrology, in: Erudition and the Republic of Letters 1 (2016), pp. 261-304; see also Klaus Oschema, Unknown or Uncertain? Astrologers, the Church, and the Future in the Late Middle Ages, in: Sibylle Baumbach / Lena HenningSen / Klaus Oschema (eds.), The Fascination with Unknown Time, London, New York 2017, pp. 93-114. 
The most prominent feature that characterizes astrologers as a group, however, is probably their academic qualification: far from being practiced in obscure circles, astrology rapidly became a subject of university curricula during the late Middle Ages. Its place in the academic system was in the Faculty of Arts, where the quadrivium of arithmetic, geometry, music (or harmony), and astronomy encompassed the mathematical disciplines, but also questions of natural philosophy. ${ }^{26}$ In addition, pertinent knowledge equally played an important role in the study of medicine, where it was considered necessary for the choice of therapies and for determining the right moment of their application. ${ }^{27}$ Towards the end of the Middle Ages, the majority of astrologers at court were often employed as physicians and disposed of a university education or even a formal degree as a master of arts or a medical doctor. ${ }^{28}$ The integration of astrology into academic teaching is in some cases attested to by the existence of pertinent teaching positions and explicit references in the curricula. ${ }^{29}$

Astrology and its practitioners thus represented a well-integrated and widely accepted feature of late medieval culture, in spite of the existing controversies: we can find numerous astrologers as advisers in courtly contexts, and even though their role for a broader public in urban and rural settings is less well-documented, some indications show that the broader population equally sought their advice. ${ }^{30}$ The subjects of this advice had virtually no limits: they ranged from the right choice of a partner and the propitious moment for marriage (including the first intercourse) ${ }^{31}$ to the right

26 See Jean-Yves Gulllaumin, La place de l'astronomie dans le quadrivium de Boèce, in: Bernard RibÉMOnT (ed.), Observer, lire, écrire le ciel au Moyen Âge, Paris 1991, pp. 115-126; John D. NORTH, The Faculty of Arts: the "Quadrivium", in: Hilde DE RidDER-SymoENS (ed.), A History of the University in Europa, vol. 1: Universities in the Middle Ages, Cambridge 1992, pp. 337-359. For the importance of 'natural philosophy' and the teaching of Aristotelian texts, see RuTKIN, How to Accurately Account (note 17), pp. 220-221, 224, who underlines the intricate relation between "natural philosophy" and the "divine/metaphysical realm".

27 See Anna Akasoy / Charles Burnett / Ronit Yoeli-Tlalim (eds.), Astro-Medicine: Astrology and Medicine, East and West (Micrologus' Library 25), Florence 2008.

28 See briefly BOUDET (note 18), pp. 296-297.

29 For Bologna see, e. g., Monica Azzolini, The Political Uses of Astrology: Predicting the Illness and Death of Princes, Kings and Popes in the Italian Renaissance, in: Studies in History and Philosophy of Biological and Biomedical Sciences 41 (2010), pp. 135-145, here pp. 140-141, and BOUDET (note 18), pp. 288-290, 302.

30 See, e. g., Sophie PAGE, Richard Trewythian and the Uses of Astrology in Late Medieval England, in: Journal of the Warburg and Courtauld Institutes 64 (2001), pp. 193-228. One indication for a broad reception is, of course, the early and impressive success of pertinent texts in print, see, e. g., GREEN (note 19).

31 For the example of Frederick III's marriage with Isabel of Aragón see Daniel Carlo PANGERL, Sterndeutung als naturwissenschaftliche Methode der Politikberatung. Astronomie und Astrologie am Hof Kaiser Friedrichs III. (1440-1493), in: Archiv für Kulturgeschichte 92(2) (2010), pp. 309-327. 
moment to start a journey, to begin a war, to lay the foundations of a city, and to the correct treatment for an illness. ${ }^{32}$

Based on the idea that foresight allowed for preparation, a locus classicus since the Hellenistic period, ${ }^{33}$ everybody could profit from pertinent information - particularly rulers. It is thus scarcely surprising that the widespread pseudo-Aristotelian 'Secretum Secretorum' explicitly invited the prince (in this case Alexander the Great, who received instructions from his teacher Aristotle) not to do anything without the advice of an astrologer, whenever possible. ${ }^{34}$ This passage not only attests to the presence of the idea in late medieval advice literature. It reminds us, furthermore, that pertinent knowledge was not only embodied by explicitly astrological writings - which, for example, represented approximately $20 \%$ of the library of King Charles V of France ${ }^{35}$ - but was also embedded in more widespread and, at first glance, inconspicuous works.

Of course, astrologers (who, as we saw, often were practising physicians) were not the only counsellors of princes: in fact, the sometimes fervent criticism and ridicule they encountered expresses the competition for the princes' ear, and the 'urban marketplace' probably saw equal rivalries. While some clerical enmity might be explained by earnest scientific and religious concerns, at least part of it resulted from the authors' preoccupation with retaining their roles as advicegiving authorities. ${ }^{36}$ Other groups of counsellors - noblemen, but also professionals like lawyers - might equally have resented the astrologers' rise from the

32 In astrological practice, these different kinds of information are discussed in well-distinguished genres: apart form the already mentioned judicia anni, which are mainly based on an individual year's 'revolution', contemporary astrologers distinguished 'nativities', 'elections', and 'interrogations', see briefly RUTKIN, Understanding the History of Astrology (note 11), p. 46, and ID., Astrology (note 11), pp. 543-544.

33 See Ptolemy, Tetrabiblos, ed. and transl. Frank Egleston RoBbins (Loeb Classical Library 435), Cambridge / MA, London 1940, pp. 20-35 (I 3); the text was made available to Latin authors through the translation by William of Moerbeke, Claudii Ptolemaei Liber iudicialium, ed. Gudrun VuilLEMin-DiEM / Carlos STEEL, Louvain-la-Neuve 2015, pp. 165-169 (c. 3), but the dictum was also transmitted via numerous other compilations. On the reception of Ptolemy in the medieval Latin West in general, see Patrick GaUTIER Dalché, La géographie de Ptolémée en Occident $\left(\mathrm{IV}^{\mathrm{e}}-\mathrm{XVI}^{\mathrm{e}}\right.$ siècle) (Terrarum orbis 9), Turnhout 2009.

34 Roger Bacon, Secretum secretorum (cum glossis et notulis), ed. Robert STEELE (Opera hactenus inedita Rogeri Baconi 5), Oxford 1920, p. 60 (I 22): O Rex clementissime, si fieri potest, non surgas nec sedeas nec comedas nec bibas et nichil penitus facias sine consilio viri periti in arte astrorum. On the 'Secretum' see most recently Catherine GaUlLIER-Bougassas / Margaret BRIDGES / Jean-Yves TilLIETTE (eds.), Trajectoires européennes du 'Secretum secretorum' du Pseudo-Aristote $\left(\mathrm{XIII}^{\mathrm{e}}-\mathrm{XVI}^{\mathrm{e}}\right.$ siècle) (Alexander redivivus 6), Turnhout 2015.

35 BOUDET (note 18), p. 304.

36 See, e. g., for Oresme Joan Cadden, Charles V, Nicole Oresme, and Christine de Pizan. Unities and Uses of Knowledge in Fourteenth-Century France, in: Edith Sylla / Michael McVAuGH (eds.), Texts and Contexts in Ancient and Medieval Science. Studies on the Occasion of John E. Murdoch's Seventieth Birthday, Leiden, New York, Cologne 1997, pp. 208-244, here pp. 235-236. 
thirteenth century onwards, but they have left fewer traces of their concerns. Even if the general picture remains patchy, due not only to the ambivalence of our sources but also to a long-lasting neglect of the question in modern research, ${ }^{37}$ we can assume that astrologers played an important role in late medieval culture in general, and as advisors in courtly contexts in particular.

\section{Asking the Obvious Question: What about Predictions that Failed?}

Acknowledging the astrologers' importance helps us considerably to better understand medieval (and more generally premodern) culture, but it also raises numerous questions. In this short article, I will limit my discussion to one of the most frequently asked questions - a question that might seem quite self-evident, but that can actually serve as an excellent example to illustrate how inquiries into medieval and modern phenomena resonate and can mutually illuminate each other: What about failure ${ }^{38}$ While belief in astrology or in astrology's scientific character is in fact still widespread in contemporary western societies, ${ }^{39}$ 'rational' modern thinking assumes that astrology does not work because it cannot (in the absence of causal effects of the stars on Earth). Astrologers' predictions are thus bound to fail. Even though the modern 'default' position might merit some qualification as far as certain details are concerned, ${ }^{40}$ let us assume that it is (and was) indeed impossible to draw meaningful conclusions about events on earth from the observation of the stars. As a consequence, the astrologers' clients must have been constantly disappointed, and in the face of this, we have to explain their continual reliance on astrological

37 Recent publications considerably broaden our knowledge, but they mostly focus on individual regional contexts, see e. g. Azzolini (note 10) (Milan), Michael A. RYAN, A Kingdom of Stargazers. Astrology and Authority in the Late Medieval Crown of Aragon, Ithaca /NY 2011 (Aragón), BouDET (note 18) (France), Laura A. Smoller, History, Prophecy, and the Stars. The Christian Astrology of Pierre d'Ailly, 1350-1420, Princeton 1994 (France), Hilary M. CAREY, Courting Disaster. Astrology at the English Court and University in the Later Middle Ages, London 1992 (England), Gerd MENTGEN, Astrologie und Offentlichkeit im Mittelalter (Monographien zur Geschichte des Mittelalters 53), Stuttgart 2005 (German courts), HAYTON (note 12) (Maximilian I).

38 The following passages partly overlap with my presentation in Klaus OSCHEMA, Irren ohne zu scheitern. Warum (spät-)mittelalterliche Astrologen nicht immer Recht haben mussten, in: Marian FüsSEL / Frank REXRoth / Inga SchÜRMANN (eds.), Praktiken und Räume des Wissens. Expertenkulturen in Geschichte und Gegenwart, Göttingen 2019, pp. 145-171.

39 ESQUERRE (note 17), pp. 19-24; see also Nick AlluM, What Makes Some People Think Astrology Is Scientific?, in: Science Communication 33(3) (2011), pp. 341-366.

40 See e. g. the infamous criticism by Paul FEYERABEND, Science in a Free Society, London 1978, pp. 91-96 (“The Strange Case of Astrology”). 
expertise. Based on this fundamental question, we can make a series of important observations.

First of all, the evidence for failure is far less abundant than one might think. Of course, we can find a number of mostly anecdotal passages in chronicles and literary texts, where critical authors indulge in mocking descriptions of astrologers' failure. Hence it is with a certain delight that Rolandino of Padova ( +1276$)$, a fervent adversary of Ezzelino da Romano, denigrates the latter as a tyrannical noblemen close to Emperor Frederick II and the worthy target of a papal crusade. According to Rolandino, Ezzelino consulted not only one but several astrologers before going to war with Milan in 1259, in order to choose the right moment for his endeavour. The outcome of the campaign - Ezzelino was injured and captured, dying shortly after the battle - underlines the author's critical stance towards astrology. ${ }^{41}$ Numerous further anecdotes made astrologers the target of ridicule; ${ }^{42}$ moreover, some adversaries of astrological practices describe in detail the fraudulent strategies astrologers used to convince their audience and acquire the favour of potential patrons. Particularly illuminating insight is furnished by Nicole Oresme, who was active at the court of Charles V of France in the second half of the fourteenth century. Oresme not only explained, based on religious and on logical arguments, why precise and individual predictions concerning human behaviour could not be made on the basis of astrological observation, but he effectively identified a series of 'psychological' tricks astrologers resorted to. These included ambivalent prognostications, which were open to later reinterpretation, as well as the use of information drawn from non-astrological sources in order to formulate predictions. ${ }^{43}$ Much of this material is, however, formulated from an explicitly inimical position and its analysis should be undertaken with caution. Evidence for the disappointment of clients who would have complained about failing prognostications or asked for explanations, is much sparser. ${ }^{44}$

Secondly, we thus have to distinguish between cases in which we can only assume that astrologers' clients should have become aware of one or more predictions' failure and other instances in which this failure was actually made explicit. Concerning the first category, Monica Azzolini provided revealing material in her masterly analysis of the reliance of the fifteenth-century dukes of Milan on astrological advice. Of particular interest is Duke Ludovico "il Moro" (r. 1494-1499), who consulted his astrologer, Ambrogio Varesi da Rosate, on a frequent basis. It seems that Ludovico often heeded Ambrogio's advice, for example on the propitious

41 See briefly MENTGEN (note 37), pp. 191-192.

42 Cf. already Theodore O. WEDEL, The Mediæval Attitude Toward Astrology, Particularly in England, New Haven, London 1920, pp. 82-87.

43 See, for example, Stefano CAROTI, Nicole Oresme: Quaestio contra divinatores horoscopios, in: Archives d'histoire doctrinale et littéraire au Moyen Âge (1976), pp. 201-310, here pp. 265-266, 307. 44 For an exceptional example see below, pp. 203-204. 
moment to begin a journey, even if this meant delaying the departure and - as scoffing observers commented - to travel finally under inclement weather conditions. ${ }^{45}$ But several of Ambrogio's predictions were clearly off: he gave erroneous dates in his predictions about the arrival of German envoys in 1493 and about the death of Pope Innocent VIII in $1492 .{ }^{46}$ But this did not discourage Ludovico from relying on his advice, possibly because the Duke tolerated a certain margin of error. ${ }^{47}$ In fact, one might ask if the Duke was actually conscious of these failures at all? As research on modern forecasts has shown, their consumers are usually not very interested in evaluating their validity in retrospect. ${ }^{48}$

An extraordinary example of the second category is furnished by the case of "Doctor Erhard Storch", a canon of the cathedral at Chur (in modern-day Switzerland) in the late fifteenth century. ${ }^{49}$ Unfortunately the material is only known to us via the 'Diarium' compiled by a contemporary priest and historiographer at Basel, Johannes Knebel, ${ }^{50}$ but there is little reason to question its authenticity. Storch is in several respects an interesting figure, not least because he was the only cleric in the entire bishopric of Chur who held a doctoral degree in medicine - an interesting combination, since clerics were generally forbidden to practice medicine. ${ }^{51}$ At the same time, his education might explain how he acquired the astrological knowledge that he drew upon in 1477, when he redacted a prognostication (probably a so-called judicium anni $)^{52}$ for the following year and published his text by attaching it to the cathedral's

45 Azzolini (see note 10), p. 174.

46 Ibid., pp. 184-185 (German envoys) and pp. 192-194 (death of Innocent VIII).

47 Ibid., p. 194. For an analogous example concerning a prediction by Paul of Middelburg at the court of Urbino in 1482 see Stephan HEILEN, Astrology at the Court of Urbino Under Federico and Guidobaldo da Montefeltro, in: Jean-Patrice Boudet / Martine Ostorero / Agostino PARAvicinI BAGLIANI (eds.): De Frédéric II à Rodolphe II. Astrologie, divination et magie dans les cours (XIII ${ }^{\mathrm{e}}$ XVII ${ }^{\mathrm{e}}$ siècle) (Micrologus' Library 85), Florence 2017, pp. 313-368, here pp. 344-345.

48 See TetLock / Gardner, Superforecasting (see note 2), pp. 52-64, who also underline the theoretical problems in evaluating the quality of forecasts.

49 Oskar VASella, Magister Artium Dr. med. Erhard Storch, Kanonikus von Chur. Das Schicksal eines Astrologen (1466-1495), in: Zeitschrift für schweizerische Kirchengeschichte / Revue d'histoire ecclésiastique suisse 53 (1959), pp. 267-289.

50 Johannes Knebel, Diarium, 2 vols., ed. Wilhelm VISCHER (Basler Chroniken 2-3), Leipzig 1880-1887, here vol. 2, pp. 251-253; on the author see Regula Schmid KeELING, Knebel, Johannes, in: Dictionnaire historique de la Suisse 7 (2008), cols 343-344. Cf. for Knebel's interest in astrology MENTGEN (note 37), pp. 266-267.

51 VASELLA (note 49), p. 268.

52 The genre appears in the late 14th century, becoming very popular toward the end of the 15th century, see the very thorough and detailed analysis by TUR, Hora introitus solis in Arietem (note 22). Cf. also briefly OsCHEMA, Zukunft gegen Patronage? (note 22), pp. 268-270; Alexandre TuR, Hartmann Schedel, collectionneur et copiste de prédictions astrologiques annuelles, in: Bulletin du bibliophile (2015), pp. 278-296, and ID., À l'entrée du Soleil en Bélier. Les prédictions astrologiques annuelles latines dans l'Europe du XV ${ }^{\mathrm{e}}$ siècle (1405-1484), Paris (unpubl. thesis, École nationale des chartes) 2014, online: http://theses.enc.sorbonne.fr/2014/tur (last accessed 15/05/2019). TUR's 
door. But his predictions failed to materialize: amongst other things he had announced the possible death of - or at least great danger to - one of the "two great lights of the Romans" (duo luminaria magna Romanorum), ${ }^{53}$ which could only be understood as an allusion to the pope and the emperor. Both survived the critical year, however, and Johannes Hopper, the provost of the cathedral church, asked for an explanation - an unusual course of action. Storch replied with a detailed letter that Knebel copied out in its entirety. ${ }^{54}$ Instead of presenting excuses for his failure, the astrologer rather gave an explanation that amounted to the principle 'trash in, trash out': in the absence of exact information on the protagonists' ascendant, Storch claimed, his predictions necessarily contained a certain margin of error, as was often the case when astrologers were asked questions but not furnished with sufficiently precise data. ${ }^{55}$ But even in spite of this problem, as he proudly underlined, some of his predictions had in fact come true, which demonstrated the enormous value and capacity of the science he practiced. ${ }^{56}$ Once again, this observation coincides with what we know about modern experts' reactions to criticism: they tend to insist on their validity, trying to claim at least partial success, rather than admitting failures that might challenge their entire model. ${ }^{57}$

Finally, a central skill of many astrologers consisted in their capacity to manoeuvre in the shallows of diverging expectations, partly by relying on the communicative strategies that have already been mentioned: their clients obviously had an interest in receiving advice that was as precise, detailed, and concrete as possible, in order to act and decide adequately. This expectation was a strong incentive for astrologers to provide suitable information, if they wanted to claim relevance. At

contributions are particularly important since most of the pertinent material has to be consulted in manuscripts and early prints: judicia anni have long been neglected in modern research and thus rarely been edited. For a notable exception see Fabrizio Bònol / Giuseppe BEZzA / Salvo DE MEIS / Cinzia Colavita (eds.), I pronostici di Domenico Maria da Novara, Florence 2012. I would like to thank H. Darrel Rutkin for bringing this edition to my attention.

53 Johannes Knebel (note 50), vol. 2, p. 251.

54 See note 50; VASELLA (note 49), pp. 273-277, provides a detailed paraphrase.

55 Johannes Knebel (note 50), vol. 2, p. 251: questioni vestre michi heri et nudiustercius proposite, videlicet cur astrologi tam sepe errare videntur, cum dicant rem aliquam tali tempore venturam, que tamen non evenire solet, satisfaciendo dico, quod hoc ideo accidit, quia gradum aliquando ascendentis precisum nativitatis vel intronizacionis ignorant. Cf. for an analogous argument John of Glogovia, Judicium anni 1476, in Munich, Bayerische Staatsbibliothek, Clm 647, fols. $21^{\mathrm{r}}-43^{\mathrm{v}}$, here fol. $37^{\mathrm{v}}$ : statum sanctissimi describere non possum, cum nec eius genitura nec sius intronisacio mihi cognita sit. See also Igor de Russia, Judicium anni 1478, in Munich, Bayerische Staatsbibliothek, Clm 647, fols. $102^{\mathrm{r}}-126^{\mathrm{r}}$, here fol. $106^{\mathrm{r}}$ : Quamquam de statu patris sanctissimi pontifici Sixti quarti judicare sit ambigium admodumque difficile cum sue sanctissime paternitatis nedum nativitas verum etiam intronizatio est incognita.

56 Johannes Knebel (note 50), vol. 2, p. 251: et quamquam aliqua eclipsis accidencia cesaree majestati evenerunt.

57 See GARDNER (note 2), pp. 203-210. 
the same time, however, several reasons induced them to remain more perfunctory: from a pragmatic perspective - and Oresme's criticism explicitly formulated this observation as a reproach - general, ambivalent, or even obscure prognostications were easier to defend after the fact, since their author could claim to have been right, whatever the outcome. ${ }^{58}$ But self-restrictions were also advisable for other reasons. A prominent discourse amongst astrologers themselves underlined the limitations of their science: according to pseudo-Ptolemy's 'Centiloquium', astrological judgements should always remain "universal” (i. e. general), advice that became a locus classicus in the pertinent literature. ${ }^{59}$ In addition to the scientific reasoning that stood behind this idea, Christian theology imposed further limitations: if individual actions could be predicted, this would imply that they were predestined and that individuals did not have a choice in their actions. Without free will, however, the Christian dogma concerning guilt and sin, which relied on the attribution of responsibility, would have been profoundly challenged. ${ }^{60}$ If they wanted to steer clear from conflicts with the church, astrologers were thus well-advised to limit their prognostications to general judgements.

But the conundrum remained, and astrologers frequently gave in to the temptation to become more precise and detailed, not least in order to highlight their ability. John Ashenden, for example, a fourteenth-century astrologer at Oxford, referred to his former successes in his voluminous 'Summa judicialis de accidentibus mundi' (1347/48, reworked c. 1365), where he proudly claimed to have predicted correctly the arrival of the Black Death in England as one of the dire consequences of the conjunction of Saturn and Jupiter in $1345 .{ }^{61}$ Possibly spurred on by this achievement, Ashenden became quite specific in a judgement on the Great Conjunction of Jupiter and Saturn in 1365, concluding that the king of England

58 CAROTI (note 43), pp. 265-266

59 The Latin text is not yet available in a critical edition. For the relevant passage in Plato of Tivoli's translation see Jean-Patrice BOUDET, Astrology between Rational Science and Divine Inspiration. The Pseudo-Ptolemy's Centiloquium, in: Stefano RAPISARDA / Erik NiblaEuS (eds.), Dialogues Among Books in Medieval Western Magic and Divination (Micrologus' Library 65), Florence 2014, pp. 49-75, here p. 62: Astrologus non debet dicere rem specialiter sed universaliter.

60 For a presentation of this discussion, which partly refers back to St Augustine, see Jan R. VEenstra, Magic and Divination at the Courts of Burgundy and France. Text and Context of Laurens Pignon's Contre les devineurs (1411) (Brill's Studies in Intellectual History 83), Leiden, New York, Cologne 1998, pp. 184-189.

61 John Ashenden, Summa judicialis de accidentibus mundi, Venice 1489, fol. 192: Omnes autem isti effectus contigerunt ex illis coniunctionibus magnis predictis sicut ostendebatur in principio huius anni 1345 in his quæ scripsimus in pronosticationibus earumdem coniunctionum. On Ashenden and his 'Summa' see Keith V. SNEDEGAR, John Ashenden and the Scientia Astrorum Mertonensis. With an Edition of Ashenden's Pronosticationes, 2 vols., Oxford (PhD, unpubl.) 1988, and CAREY (note 37), pp. 73-78, 85-91. 
would receive the kingdom of France. ${ }^{62}$ In the immediate aftermath of the overwhelming English military success against the French at Poitiers (1356) and with King John II of France in captivity, many contemporaries would probably not have considered this prediction to be improbable, even if it only partially came true for Henry $\mathrm{V}$ in the early fifteenth century. From a strictly systematic perspective, however, it formulated a quite specific outcome, although Ashenden refrained from describing individual actions. ${ }^{63}$

In order to defend themselves against religious or theological reproach, astrologers often referred to yet another phenomenon that also helped in the defence against accusations of failure: especially in judicia anni, a kind of 'everyday literature' in this field, we repeatedly find the assertion that the author did his best to interpret the stellar signs according to tradition and astrological authorities. In spite of this effort, God could obviously always choose to alter the train of events. ${ }^{64}$ This argument, often accompanied by the assurance that nothing heretical was intended, did not actually address the problem of human free will, but it guaranteed God's free choice and omnipotence. At the same time, it provided an efficient defence against the reproach of failure - who was to blame the astrologer if God decided to intervene?

\section{Consequences? Medieval and Modern ...}

The vast range of implications resulting from this small sample of observations cannot be analysed in detail here, but the limited selection already furnishes telling material that allows us to gauge the potential of comparative approaches to medieval and modern expertise. To start with, one might underline what could be called the 'precision-conundrum': when it comes to forecasts, which are inevitably prone to be proven wrong as events unfold, the different social actors behave according to profoundly different interests. While their clients ask for detailed and precise information, the experts have an interest in leaving a certain margin for interpretation in order to be able to defend their prognostications later on. If they want to remain

62 John Ashenden, Pronosticatio coniunctionis magne Saturni et Jovis anno Christi 1365, Oxford, Bodleian Library, ms Digby 176, fols. $42^{\mathrm{r}}-49^{\mathrm{v}}$, here fol. $47^{\mathrm{r}}$. The treatise can be dated to 1357 , see CAREY (note 37), p. 87. For an instructive presentation of the theory on conjunctions, esp. the fundamental importance of 'Great Conjunctions' of Saturn and Jupiter, see John D. NoRTH, Astrology and the Fortune of Churches, in: Centaurus 24(1) (1980), pp. 181-211, and briefly Smoller (note 37), p. 19-22.

63 For Ashenden's strategy to steer clear of too precise predictions see CAREY (note 37), pp. 75-76. 64 See e. g. Johannes Laet de Borchloen, Iudicium anni 1478, Munich, Bayerische Staatsbibliothek, Clm 647 , fols. $88^{\mathrm{v}}-101^{\mathrm{v}}$, here fol. $90^{\mathrm{r}}$ : Et noverit vestre illustrissime pater mee fore mentis et intencionis de subscriptis, quod in eventum quo quis me maligno harum reprehendere molitus fuerit (quod Deus avertat) quod Deus omnipotens creator planetarum omniam supernaturaliter inmutare posset, addendo vel minuendo. 
interesting to their clients or audience, however, they need to at least conjure up the impression of relevance by, for example, providing details and by claiming a high degree of certainty. While modern experts mainly rely on the notion of probability in order to navigate between precise indications and the attempt to provide for a margin of error, late medieval astrologers accomplished a comparable effect by (a) referring to God's capacity to change the natural course of events, (b) to the deficient quality of the data they received for their calculations, and (c) to the conjectural nature of astrological predictions (as opposed to the astronomical calculations they were based on). At the same time, they ceaselessly underlined the fact that they practised a science, which was prone to produce reliable results. ${ }^{65}$ Even though their techniques partly differ, modern and medieval experts alike (mostly) successfully create the appearance of providing a secure basis for decision making. Both also profit from underlying effects in human cognition, since we often tend to ascribe a higher degree of certainty to information than the individual authors actually claim. ${ }^{66}$

Late medieval criticism of astrology contains many motifs that sound familiar when considered alongside the modern discourse about experts. Seen from this perspective, inquiries into the perception of astrologers as late medieval experts provide evidence for historical precedents of insights into the working of the human mind and into the haziness of communication. ${ }^{67}$ But they do more than that: if medievalists want to understand the mechanisms at play in these contexts adequately, they have much to learn from insights provided by the Social Sciences. Their results actually force us to recognize that human behaviour and attitudes are often characterized by irrational features: to mention but one example, humans are easily convinced by the presence of supposed arguments, even if these do not logically relate to the matter at hand. ${ }^{68}$ In addition, our thoughts and conclusions are heavily influenced by secondary, incidental, and non-related input or information. ${ }^{69}$ In sum, this implies that not every seemingly fraudulent behaviour is actually fraudulent,

65 See, for example, the introductory remarks by Cecco d'Ascoli, In spheram mundi, in: Lynn Thorndike (ed.), The Sphere of Sacrobosco and its Commentators, Chicago 1949, pp. 343-412, here p. 346: sub excellentiori modo per scientiam stellarum habetur futurorum cognitio veritatis.

66 On pertinent effects see TETLOCK / GARDNER, Superforecasting (note 2), pp. 137-143, here p. 140: "But the way people think, they seem to translate a high probability into 'this will happen'." (The authors quote Robert Rubin, a former Treasury secretary.)

67 See, for example, the comments by Oresme (see note 43).

68 Ellen J. LANGER / Arthur Blank / Benzion ChANOwITZ, The Mindlessness of Ostensibly Thoughtful Action: The Role of "Placebic" Information in Interpersonal Interaction, in: Journal of Personality and Social Psychology 36(6) (1978), pp. 635-624; cf. Daniel T. WiLlingham, When Can You Trust the Experts? How to Tell Good Science from Bad in Education, San Francisco 2012, pp. 31-32. See more generally Daniel Kahneman, Thinking, Fast and Slow, New York 2011.

69 For a detailed presentation see Hugo MERCIER / Dan SPERBER, The Enigma of Reason. A New Theory of Human Understanding, London 2017. 
since (in the astrologers' case) both the astrologers and their clients might have been equally convinced they were engaged in an earnest and serious endeavour. Consequently, reliance on astrological advice cannot be interpreted simply as a sign of superstition and naive credulity; it rather expresses the desire to act on the grounds of the best available information.

While these observations considerably modify our ideas of an important aspect of late medieval culture - arguing for the existence of a 'culture of expertise' in this period $^{70}$ - they also invite us to reflect anew about our own practices in relation to experts and expertise. As the events of the financial crisis that escalated in 2007 demonstrated, the information of an important group of economic and financial experts was, to say the least, of limited value. Moreover, many of these experts did not suffer any sustained negative consequences of their failure - and at this point late medieval and modern phenomena begin to mutually illuminate each other: the fact that failure does not make a decisive difference can also partly be explained with features that characterize human thinking and perception, including a certain confirmation bias, the tendency to suppress data that conflicts with our basic convictions, and the lack of interest in evaluating past forecasts. ${ }^{71}$ A comparative look at medieval and modern expertise in prognostication can make us realise that both rely heavily on belief in spite of their claims to a scientific character, which are underlined by their empirical basis, their mathematical approaches, and their elaborate set of rules for interpretation. In this sense, the analysis of a medieval phenomenon - by means of modern social scientific theories and insights - enables us to develop new critical perspectives on our own world and its workings and on our well-established, albeit erroneous, self-description as 'rational' ${ }^{72}$ It seems to me that this opening of a new perspective on contemporary phenomena, which is based on the identification of common cultural traits on a structural level, constitutes a clear argument for the relevance of research in Medieval Studies.

70 For a brief definition see Philip KnäBle, Einleitung, in: ID. / Marian FÜSSEL / Nina ElSEMANN (eds.), Wissen und Wirtschaft. Expertenkulturen und Märkte vom 13. bis 18. Jahrhundert, Göttingen 2017, pp. 9-30, here pp. 11-12; see also Frank ReXrotH, Systemvertrauen und Expertenskepsis. Die Utopie vom maßgeschneiderten Wissen in den Kulturen des 12. bis 16. Jahrhunderts, in: ID. / Björn REICH / Matthias RoICK (eds.), Wissen, maßgeschneidert. Experten und Expertenkulturen im Europa der Vormoderne (Historische Zeitschrift. Beihefte N.F. 57), Munich 2012, pp. 12-44. The figure of the 'expert' has recently been repeatedly discussed in medieval studies; see, for example, the contributions to Thomas BÉNATOUÏL / Isabelle DRAELANTS (eds.), Expertus sum. L'Expérience par les sens dans la philosophie médiévale (Micrologus' Library 40), Florence 2011; Hedwig RöcKELEIN / Udo FRIEDRICH (eds.), Experten der Vormoderne zwischen Wissen und Erfahrung (Das Mittelalter 17[2]), Berlin 2012; SHMESP (ed.), Experts et expertise au Moyen Âge. Consilium quaeritur a perito (Histoire ancienne et médiévale 116), Paris 2012.

71 See note 2.

72 See GoBEt (note 2), pp. 85-86, on the notion of "bounded rationality". 
But the potential insights go even further, because it would be short-sighted to simply dismiss the failing experts and their services as useless: even though their predictions are inevitably flawed, since the future is fundamentally unpredictable, they go a long way in helping the individual to ameliorate her or his vision of the respective present, precisely because they strive to deliver a diagnosis that is as complete as possible in order to lay out the panorama of future developments. In doing so, and moreover in a systematic way, they inform their readers or listeners about things that they should take into consideration before making up their minds. This effect becomes very clear when we look at the systematic writings of late medieval astrologers. Recognizing this goes a long way towards developing a new perspective on late medieval culture, one that is different from the established 'superstition narrative'. At the same time, this insight, which can be formulated in a clear way for this distant period, can open our eyes to the effects that play out in the present day: accepting the forecasts of financial or economic experts amounts to an act of belief. In addition, the lay of the land they develop in order to produce a basis for the prognosis can still furnish a valuable overview and important insights. So, in the end, analysing the features of an expert culture that is distant in time can actually help us to better understand our present in a very concrete way. 
